\title{
Assessment of Haematological Parameters of Pulmonary Tuberculosis Patients with and Without HIV Infection Attending Two Secondary Health Facilities in Jigawa State
}

\author{
Baballe Abbas ${ }^{1,}$, , Musa Mustapha Dogara ${ }^{2}$, Nura Muhammad Sani ${ }^{1}$, Ahmad Mohammed Gumel ${ }^{1}$, \\ Danjuma Lawal ${ }^{1}$
}

${ }^{1}$ Department of Microbiology and Biotechnology, Federal University Dutse, Dutse, Jigawa State, Nigeria

${ }^{2}$ Department of Biological Sciences, Federal University Dutse, Dutse, Jigawa State, Nigeria

Email address:

bagwarame@gmail.com (B. Abbas)

${ }^{*}$ Corresponding author

\section{To cite this article:}

Baballe Abbas, Musa Mustapha Dogara, Nura Muhammad Sani, Ahmad Mohammed Gumel, Danjuma Lawal. Assessment of Haematological Parameters of Pulmonary Tuberculosis Patients with and Without HIV Infection Attending Two Secondary Health Facilities in Jigawa State. International Journal of Microbiology and Biotechnology. Vol. 5, No. 3, 2020, pp. 103-109.

doi: $10.11648 /$ j.ijmb.20200503.15

Received: May 4, 2020; Accepted: June 15, 2020; Published: June 29, 2020

\begin{abstract}
TB and HIV form a lethal combination, as each fuels the progress of the other in the infected patients. This study assessed the haematological parameters of pulmonary tuberculosis (PTB) patients with and without HIV infection attending the two secondary health facilities in Jigawa State, Nigeria. A total of 150 PTB patients visiting the two secondary health facilities were randomly selected for the study. $5 \mathrm{ml}$ of venous blood was drawn aseptically with the help of sterile syringe using vein puncture technique and transferred into EDTA bottle to avoid coagulation. $2 \mathrm{ml}$ of the EDTA blood was transferred in to plane test tube for the haematological analysis using automated Haematological Analyser (Abacus Junior 380) while the remaining $3 \mathrm{ml}$ of the blood was placed into a Western green tube up to the zero mark for Erythrocyte sedimentation rate (ESR) determination. The data was analysed using SPSS version 20, One-way ANOVA was used to check the significant difference among the new, follow-up and Multi drug resistant TB (MDR-TB) groups of patients. $136(90.67 \%)$ patients were HIV negative and $14(9.33 \%)$ were HIV positive, $95(63.33 \%)$ were males and $55(36.37 \%)$ were females. Among the studied population $56(37.33 \%)$ and 94 (62.67\%) were new and followup PTB patients respectively. In this study, there were significantly lower mean values at $(\mathrm{P}>0.05)$ of White blood cells, lymphocytes, neutrophils (MID), granulocytes, Red Blood Cells, packed cells volume, and Platelets counts among PTBHIV co-infected patients when compared with PTB patients. Of the PTB patients, 27.94\% were Leukopenic, $25.7 \%$ Lymphopenic, $26.47 \%$ neutropenic, $30.88 \%$ anaemic and $20.59 \%$ thrombocytopenic. On the other hand, of the PTB-HIV co-infected patients, $64.29 \%$ were leukopenic, $35.71 \%$ lymphopenic, $26.47 \%$ neutropenic, $21.43 \%$ anaemic, and $14.29 \%$ thrombocytopenic. This study demonstrated high prevalence of leucopenia, followed by neutropenia and anaemia, lymphopenia, and thrombocytopenia. There was also high ESR values among more than two-third of the 150 PTB patients. The study also revealed that, females were more co-infected with HIV $64.29 \%$ than the males with $35.71 \%$. HIV co-infection worsens haematological abnormalities of PTB patients. Knowledge of these haematological parameters will enhance the overall management of the PTB patients with regard to monitoring the disease progression and response to antimicrobial chemotherapy as they will serve as useful indicators for treatment success or failure. It is recommended that all newly diagnosed and follow-up PTB and PTB-HIV co-infected patients should be exposed to haematological counts to monitor their immune status.
\end{abstract}

Keywords: Pulmonary Tuberculosis, Human Immunodeficiency Virus, Haematological Parameters, New TB Patients, Follow up TB Patients, Erythrocyte Sedimentation Rate 


\section{Introduction}

Tuberculosis, commonly known as TB, is a bacterial infection that usually affects the lungs but could also affect all parts of the body, with exception of nails and hair. The causative organism Mycobacterium tuberculosis was first discovered in 1882 by Robert Koch. The physiology of $M$. tuberculosis is highly aerobic and requires high levels of oxygen. The M. tuberculosis genome was sequenced in 1998 [1]. Unlike HIV (Human Immunodeficiency Virus), TB is completely preventable and treatment is a fraction of the cost of medications used to treat HIV. When a person is infected with $\mathrm{HIV}$, he/she is at an increased risk of also contracting TB due to his/her low immune status caused by the virus. HIV co-infection with TB can also mean an accelerated progression to AIDS. Tuberculosis can be latent or active. Close to one-third of the world's population has dormant or latent TB. TB continues to be the top infectious killer worldwide, claiming over 4,500 lives a day [2]. In 2018, 10 million people fell ill with TB and 1.5 million died from the disease [2]. 2018's Global TB report ranked Nigeria $4^{\text {th }}$ in terms of TB burden which makes it among the six countries that accounted for $60 \%$ of the new cases of TB. The country is also classified among countries with high burden for TB, TB/HIV and Multidrug-resistant TB (MDR-TB) and currently ranked $6^{\text {th }}$ and $1^{\text {st }}$ in Africa [3].

HIV continues to be a global public health issue, having claimed more than 35 million lives so far [4]. Nigeria has the second largest HIV epidemic in the world [5]. HIV and TB are deadly combination, as each fuels the progress of the other in infected patients [6]. Persons who are infected with HIV are prone to TB disease than those without HIV infection. The demonstrable changes that PTB, and/or PTB plus HIV positive patients have in their haematological values showed varied pictures as a result of the phase of the infection and the causative agents, M. tuberculosis and HIV [7]. Haematological parameters are the blood forms (Red Blood Cells, White Blood Cells, and Platelets) with normal range as reference for any value to know whether or not they are normal [8]. Haematological abnormalities are common in PTB patients [9].

There are limited studies conducted on the haematological parameters of pulmonary tuberculosis patients with and without HIV in infection in developing countries, especially in Nigeria. There is scarcity of data in Nigeria that assessed the haematological parameters of PTB Patients with and without HIV infection in order to diagnose changes in these parameters and monitor treatment outcome of the patients. Hence, this study was aimed to assessing the haematological abnormalities among PTB patients with and without HIV infection attending two secondary health facilities in Jigawa State, Nigeria.

\section{Materials and Methods}

\subsection{Study Area}

The study areas were Hadejia and Kafin Hausa towns in
Hadejia Emirate, North-Eastern part of Jigawa State. Hadejia town which is the capital of the emirate has a projected population of 139,400 people as at $21^{\text {st }}$ March, 2016 [10]. The town lies to the north of the Hadejia River, and is upstream from the Hadejia-Nguru wetlands, an internationally important ecological and sensitive zone. Hadejia is located at Latitude: $12^{\circ} 27^{\prime} 59^{\prime} \mathrm{N}$ and Longitude $10^{\circ} 3^{\prime} 40^{\prime \prime} \mathrm{E}$ and it is $361 \mathrm{~m}$ above Sea level with an area of $32.0 \mathrm{Km}^{2}[10]$. Kafin Hausa town is the capital of KafinHausa Local Government Area and is located at Latitude: $12^{\circ} 14^{\prime} 27.6$ 'N and Longitude $9^{\circ} 54^{\prime} 46.8^{\prime \prime} \mathrm{E}$. It has a projected population of 357,200 as at $21^{\text {st }}$ March, 2016 [10].

\subsection{Study Design, Sample Size and Population}

The study design was both across sectional and descriptive design. A total of 150 new and follow-up pulmonary tuberculosis patients with and without HIV infection were randomly selected for the study. A patient was classified as pulmonary tuberculosis patient if all or one out of the two sputum samples collected in the laboratory were or was positive for Acid Fast Bacilli (AFB), chest X-ray and clinical symptoms were suggestive of the disease, or his/her sputum sample was detected for PTB during Gene-Xpert techniques.

The study population was categorized as those who had only PTB and PTB-HIV co-infection, new and follow-up PTB patients, the follow-up patients were also classified as those at intensive phase of treatment and those at their continuation phase of treatment.

\subsection{Exclusion Criteria}

PTB patients with bleeding manifestations, chronic inflammatory disease, pregnant or breast feeding women were excluded as these clinical conditions may also alter the patient's haematological parameters.

\subsection{Samples Collection and Processing}

About 4-5ml of venous blood was drawn aseptically with the help of sterile syringe and transferred in to EDTA bottle to avoid coagulation. $2 \mathrm{ml}$ of the EDTA blood was transferred in to a plane test tube for the haematological analysis using the Automated Haematological Analyser (Sysmex, KX-21N) in one of the health facility and (Abacus Junior 380) in the other one. The remaining $3 \mathrm{ml}$ of the blood was drawn in to a Western Green Tube up to the zero mark for Erythrocyte Sedimentation Rate (ESR) determination. The tube was placed vertically in an ESR stand for one hour and the reading for each patient was recorded.

\subsection{Data Analysis}

The data was analysed using Statistical package of Social Science (SPSS. version 20) software and One-way analysis of variance (ANOVA) was used to check the significant 
difference among the new, follow-up, and Multi drug resistant PTB groups of patients. SAS version 9.1software was also applied in the analysis of data among PTB with or without HIV co-infection, to determined Correlation matrix for all the assessed parameters, age and gender to check the possible relationship between the variables using One-way analysis of variance. Duncan's Multiple Range Test (DMRT) was used to separate means where differences existed.

\subsection{Ethic Statement}

An ethical approval with reference number: MOH/SEC. 3/S/711/I/21 dated $5^{\text {th }}$ July, 2018 was obtained from Jigawa State Ministry of Health, Dutse and written permission from Medical Directors of the two Secondary health facilities dated $20^{\text {th }}$ July, 2018 and $10^{\text {th }}$ July, 2018 respectively was obtained. Informed consent of all the participants was obtained and were given the option to opt out any time they desire to do so during the work.

\section{Results}

\subsection{Characteristics of the Study Participants}

A detail of the characteristics of the study participants is presented in Table 1. 136 (90.67\%) were HIV negative and $14(9.33 \%)$ were co-infected with HIV in addition to the PTB infection. $95(63.33 \%)$ were males and 55 (36.67\%) were females, among the males 90 (94.74\%) have only PTB infection while $5(5.26 \%)$ have both PTB and HIV infections. $46(83.64 \%)$ of the females have only PTB infection while 9 $(16.36 \%)$ have both infections. $56(37.33 \%)$ and $94(62.67 \%)$ were PTB new and Follow-up patients respectively, out of the 94 follow-up PTB patients, 43 (45.74\%) were at Intensive Phase of their treatment while $51(54.26 \%)$ were at the Continuation Phase of their treatment. Among the 43 Intensive Phase PTB patients, 3 (6.28\%) were PTB/HIV coinfected patients while the rest have only PTB disease. As for those in Continuation Phase of treatment 46 (90.20\%) and 5 (9.80\%) have PTB and PTB/HIV infections respectively. The mean age of the participants was $48 \pm 10$ years.

Table 1. Characteristics of the study population of the two secondary facilities.

\begin{tabular}{llll}
\hline Characteristics & TB (\%) & PTB/HIV Negative (\%) & PTB/HIV Positive (\%) \\
\hline & $\mathbf{n = 1 5 0}$ & $\mathbf{n = 1 3 6}(\mathbf{9 0 . 6 7 \% )}$ & $\mathbf{n = 1 4}(\mathbf{9 . 3 3 \% )}$ \\
\hline Age group (years) & & & \\
$08-17$ & $12(8.00 \%)$ & $12(8.82 \%)$ & $0(00.00 \%)$ \\
$18-27$ & $34(22.67 \%)$ & $31(22.79 \%)$ & $3(21.43 \%)$ \\
$28-37$ & $45(30.00 \%)$ & $42(30.88 \%)$ & $3(21.43 \%)$ \\
$38-47$ & $30(20.00 \%)$ & $24(17.65 \%)$ & $6(42.86 \%)$ \\
$48-57$ & $14(09.33 \%)$ & $12(08.82 \%)$ & $2(14.28 \%)$ \\
$58-67$ & $09(06.00 \%)$ & $09(06.62 \%)$ & $0(00.00 \%)$ \\
$68-77$ & $05(03.33 \%)$ & $05(03.68 \%)$ & $0(00.00 \%)$ \\
$78-87$ & $01(00.67 \%)$ & $01(00.74 \%)$ & $0(00.00 \%)$ \\
Gender & & & $5(35.71 \%)$ \\
Male & $95(63.33 \%)$ & $90(66.18 \%)$ & $9(64.29 \%)$ \\
Female & $55(36.67 \%)$ & $46(33.82 \%)$ & $6(42.86 \%)$ \\
PTB Status & & & $8(57.14 \%)$ \\
New Patients & $56(37.33 \%)$ & $50(36.76 \%)$ & $\mathrm{n}=8$ \\
Follow-up Patients & $94(62.67 \%)$ & $86(63.24 \%)$ & $3(37.50 \%)$ \\
Follow-up Patients & $\mathrm{n}=94$ & $\mathrm{n}=86$ & $5(62.50 \%)$ \\
Intensive Phase Patients & $43(45.74 \%)$ & $40(46.51 \%)$ & $46(53.49 \%)$ \\
Continuation Phase patients & $51(54.26 \%)$ & & \\
\hline
\end{tabular}

\subsection{Haematological Profiles of PTB/HIV Negative and PTB/HIV Positive Patients}

The haematological profiles of the participants displayed in Table 2 revealed that the mean value of total White Blood Cells $\left(\mathrm{WBC}\right.$ ) count was $8.11 \times 10^{9} / \mathrm{L}$ for PTB/HIV negative patients and $5.26 \times 10^{9} / \mathrm{L}$ for $\mathrm{PTB} / \mathrm{HIV}$ positive patients, Lymphocytes (LYMP) count was $2.29 \times 10^{9} / \mathrm{L}$ for $\mathrm{PTB} / \mathrm{HIV}$ negative and $1.93 \times 10^{9} / \mathrm{L}$ for $\mathrm{PTB} / \mathrm{HIV}$ positive patients, MID count was found to be $1.11 \times 10^{9} / \mathrm{L}$ for $\mathrm{PTB} / \mathrm{HIV}$ and $0.70 \times 10^{9} / \mathrm{L}$ for $\mathrm{PTB} / \mathrm{HIV}$ co-infected patients, Granulocytes (GRA) count was $4.48 \times 10^{9} / \mathrm{L}$ and $2.80 \times 10^{9} / \mathrm{L}$ for PTB/HIV negative and PTB/HIV positive patients respectively. Red Blood Cells (RBC) count was $5.23 \times 10^{12} / \mathrm{L}$ for PTB /HIV negative patients and $5.15 \times$ $10^{12} / \mathrm{L}$ for PTB/HIV positive patients while $46.65 \%$ and $44.37 \%$ were found as Packed Cells Volumes (PCV) of the
PTB/HIV negative and PTB/HIV positive patients respectively. Mean (red) cell volume (MCV) count was 93.93 (fl) for PTB/HIV negative patients and 86.68 (fl) for PTB/HIV positive patients, 26.84 (pg) and 25.59 (pg) were recorded as the Mean Cell Haemoglobin $(\mathrm{MCH})$ of the $\mathrm{PTB} / \mathrm{HIV}$ negative and PTB/HIV positive patients respectively while the Mean Cell Haemoglobin Concentration (MCHC) count was found to be $29.89(\mathrm{~g} / \mathrm{dl})$ for PTB/HIV negative and $29.09(\mathrm{~g} / \mathrm{dl})$ for PTB/HIV positive patients. The Platelet (PLT) count was $317.16 \times$ $10^{9} / \mathrm{L}$ and $291.50 \times 10^{9} / \mathrm{L}$ for $\mathrm{PTB} / \mathrm{HIV}$ negative and PTB/HIV positive patients respectively, Mean Platelet Volume (MPV) was 9.98 for PTB/HIV negative and 9.79 for PTB/HIV positive patients, and finally the mean Erythrocyte Sedimentation Rate (ESR) was found to be $44.45 \mathrm{~mm} / \mathrm{hr}$ for PTB/HIV negative patients and 52.57 $\mathrm{mm} / \mathrm{hr}$ for $\mathrm{PTB} / \mathrm{HIV}$ positive patients at $(\mathrm{P}>0.05)$. 
Table 2. Haematological Parameters among Pulmonary Tuberculosis Patients with and without HIV co-infection in the study area.

\begin{tabular}{|c|c|c|c|c|}
\hline Parameters & PTB & PTB (HIV -ve) & PTB (HIV +ve) & WHO (2019) Normal range \\
\hline $\mathrm{WBC}\left(\times 10^{9} / 1\right)$ & $8.29 \pm 0.13^{\mathrm{a}}$ & $8.11 \pm 0.03^{\mathrm{a}}$ & $5.26 \pm 0.29^{\mathrm{b}}$ & $5.00-10.00$ \\
\hline $\operatorname{LMP}\left(x 10^{9} / 1\right)$ & $2.26 \pm 0.90^{\mathrm{a}}$ & $2.29 \pm 0.90^{\mathrm{a}}$ & $1.93 \pm 0.02^{\mathrm{a}}$ & $1.30-4.00$ \\
\hline $\operatorname{MID}\left(x 10^{9} / 1\right)$ & $1.20 \pm 0.25^{\mathrm{a}}$ & $1.11 \pm 0.43^{\mathrm{a}}$ & $0.70 \pm 0.56^{\mathrm{b}}$ & $0.59-0.70$ \\
\hline $\operatorname{GRA}\left(\times 10^{9} / 1\right)$ & $4.66 \pm 0.03^{\mathrm{a}}$ & $4.48 \pm 0.83^{\mathrm{a}}$ & $2.80 \pm 0.08^{\mathrm{a}}$ & $2.50-7.50$ \\
\hline $\operatorname{RBC}\left(\times 10^{12} / 1\right)$ & $5.15 \pm 0.28^{\mathrm{a}}$ & $5.23 \pm 0.28^{\mathrm{a}}$ & $5.15 \pm 0.67^{\mathrm{a}}$ & $4.00-5.50$ \\
\hline PCV (\%) & $42.72 \pm 0.23^{\mathrm{a}}$ & $46.65 \pm 2.93^{\mathrm{a}}$ & $44.37 \pm 0.83^{\mathrm{a}}$ & $36.00-52.00$ \\
\hline $\operatorname{MCV}(\mathrm{fl})$ & $87.67 \pm 1.20^{\mathrm{a}}$ & $93.93 \pm 2.89^{\mathrm{a}}$ & $86.68 \pm 0.71^{\mathrm{b}}$ & $76.00-96.00$ \\
\hline $\mathrm{MCH}(\mathrm{pg})$ & $25.40 \pm 0.26^{\mathrm{a}}$ & $26.84 \pm 0.23^{\mathrm{a}}$ & $25.59 \pm 0.23^{\mathrm{a}}$ & $27.00-32.00$ \\
\hline $\operatorname{MCHC}(\mathrm{g} / \mathrm{dl})$ & $32.03 \pm 1.73^{\mathrm{a}}$ & $29.89 \pm 0.68^{\mathrm{a}}$ & $29.09 \pm 0.89^{\mathrm{a}}$ & $30.00-35.00$ \\
\hline $\operatorname{PLT}\left(\times 10^{9} / 1\right)$ & $323.04 \pm 5.42^{\mathrm{a}}$ & $317.16 \pm 0.98^{\mathrm{a}}$ & $291.50 \pm 0.03^{\mathrm{a}}$ & $150.00-400.00$ \\
\hline MPV & $10.12 \pm 0.23^{\mathrm{a}}$ & $9.98 \pm 0.82^{\mathrm{a}}$ & $9.79 \pm 0.34^{\mathrm{a}}$ & $8.00-15.00$ \\
\hline $\operatorname{ESR}(\mathrm{mm} / \mathrm{hr})$ & $54.54 \pm 4.75^{\mathrm{a}}$ & $44.45 \pm 0.71^{\mathrm{a}}$ & $52.57 \pm 3.12^{\mathrm{a}}$ & $<20$ \\
\hline
\end{tabular}

Means with the same superscript are not significantly different $(\mathrm{P}>0.05)$ along the rows.

\subsection{Haematological Disorders Among PTB Patients with and Without HIV Infection}

The profile of haematological disorders of PTV patients with and without HIV infection is shown in Table 3. Among the $136 \mathrm{PTB} / \mathrm{HIV}$ negative group 38 (27.94\%) have low and high WBC counts each, while in the $14 \mathrm{PTB} / \mathrm{HIV}$ co-infected patients 9 (64.29\%) and $2(14.29 \%)$ have low and high WBC count respectively. Lymphocytes count of PTB/HIV negative patients showed $35(25.74 \%)$ have low count and $12(8.82 \%)$ have high count outside the normal range values while for the PTB/HIV patients $5(35.71 \%)$ have low lymphocytes count and only $1(7.14 \%)$ had higher values. MID count among the same group showed that $36(26.47 \%)$ and 74 (54.41\%) have low and high values respectively, while among the PTB/HIV positive patients $9(64.29 \%)$ have low MID count and 5 (35.71\%) have high count beyond the normal range. Granulocytes count of the PTB/HIV negative shows that, 51 (37.50\%) have low count and $22(16.18 \%)$ have high GRA count as the PTB/HIV positive group have 9 (64.28\%) with low and 2 (14.29\%) having higher values.

For RBC count of PTB/HIV negative patients, 35 (22.74\%) have low count and $48(35.29 \%)$ have high count than the normal range while in the $\mathrm{PTB} / \mathrm{HIV}$ positive patients, $5(35.71 \%)$ and $6(42.86 \%)$ have low and elevated RBC counts respectively. PCV results of the Patients having only PTB infection showed $42(30.88 \%)$ with anaemia and $30(22.06 \%)$ with high readings outside the normal range values while in the case of PTB/HIV positive patients 3 $(12.43 \%)$ have low and high PCV results each. Platelets counts of PTB/HIV negative group of patients reflected 28 $(20.59 \%)$ out of 136 to have low platelets count and 41 (30.15\%) with higher counts, while among the PTB/HIV positive patients $2(14.29 \%)$ have low count and $4(28.57 \%)$ high count. In the case of ESR 86 (63.24\%) of the PTB/HIV negative patients have high rate of sedimentation above the normal values while $10(71.43 \%)$ PTB/HIV positive patients also have high rate.

Table 3. Haematological Parameters among the Pulmonary Tuberculosis Patients.

\begin{tabular}{|c|c|c|c|c|}
\hline \multirow{2}{*}{ Parameters } & \multirow{2}{*}{ Normal range Values } & \multirow{2}{*}{$\begin{array}{l}\text { PTB (\%) } \\
n=150\end{array}$} & \multirow{2}{*}{$\begin{array}{l}\text { PTB/HIV Negative (\%) } \\
n=136(90.67 \%)\end{array}$} & \multirow{2}{*}{$\begin{array}{l}\text { PTB/HIV positive (\%) } \\
\mathrm{n}=14(9.33 \%)\end{array}$} \\
\hline & & & & \\
\hline $\mathrm{WBC} \times 10^{9} / \mathrm{L}$ & $5.00-10.00$ & & & \\
\hline High & & $40(26.67 \%)$ & 38 (27.94\%) & $2(14.29 \%)$ \\
\hline Normal & & $63(42.00 \%)$ & $60(44.12 \%)$ & $3(21.42 \%)$ \\
\hline Low & & $47(31.33 \%)$ & $38(27.94 \%)$ & $9(64.29 \%)$ \\
\hline LYMP $\times 10^{9} / \mathrm{L}$ & $1.30-4.00$ & & & \\
\hline High & & $13(8.67 \%)$ & $12(8.82 \%)$ & $1(7.14 \%)$ \\
\hline Normal & & $97(64.67 \%)$ & 89 (65.44\%) & $8(57.14 \%)$ \\
\hline Low & & $40(26.66 \%)$ & 35 (25.74\%) & $5(35.71 \%)$ \\
\hline MID $\times 10^{9} / \mathrm{L}$ & $0.59-0.70$ & & & \\
\hline High & & $79(52.67 \%)$ & 74 (54.41\%) & $5(35.71 \%)$ \\
\hline Normal & & $26(17.33 \%)$ & $26(19.12 \%)$ & $0(00.00 \%)$ \\
\hline Low & & $45(30.00 \%)$ & $36(26.47 \%)$ & $9(64.29 \%)$ \\
\hline GRA $\times 10^{9} / \mathrm{L}$ & $2.50-7.50$ & & & \\
\hline High & & $24(16.00 \%)$ & $22(16.18 \%)$ & $2(14.29 \%)$ \\
\hline Normal & & $66(44.00 \%)$ & $63(46.32 \%)$ & $3(21.43 \%)$ \\
\hline Low & & $60(40.00 \%)$ & $51(37.50 \%)$ & $9(64.28 \%)$ \\
\hline $\mathrm{RBC} \times 10^{12} / \mathrm{L}$ & $4.00-5.50$ & & & \\
\hline High & & $54(36.00 \%)$ & 48 (35.29\%) & $6(42.86 \%)$ \\
\hline Normal & & $56(37.33 \%)$ & $53(38.97 \%)$ & $3(21.43 \%)$ \\
\hline Low & & $40(26.67 \%)$ & $35(25.74 \%)$ & $5(35.71 \%)$ \\
\hline PCV (\%) & $36.00-52.00$ & & & \\
\hline High & & $33(22.00 \%)$ & $30(22.06 \%)$ & $3(21.43 \%)$ \\
\hline
\end{tabular}




\begin{tabular}{|c|c|c|c|c|}
\hline \multirow{2}{*}{ Parameters } & \multirow{2}{*}{ Normal range Values } & \multirow{2}{*}{$\begin{array}{l}\text { PTB (\%) } \\
n=150\end{array}$} & \multirow{2}{*}{$\begin{array}{l}\text { PTB/HIV Negative (\%) } \\
\mathrm{n}=136(90.67 \%)\end{array}$} & \multirow{2}{*}{$\begin{array}{l}\text { PTB/HIV positive (\%) } \\
\mathrm{n}=14(9.33 \%)\end{array}$} \\
\hline & & & & \\
\hline Normal & & $72(48.00 \%)$ & $64(47.06 \%)$ & $8(57.14 \%)$ \\
\hline Low & & $45(30.00 \%)$ & $42(30.88 \%)$ & $3(21.43 \%)$ \\
\hline $\operatorname{MCV}(\mathrm{fl})$ & $76.00-96.00$ & & & \\
\hline High & & $34(22.67 \%)$ & $29(21.32 \%)$ & $5(35.71 \%)$ \\
\hline Normal & & $96(64.00 \%)$ & $88(64.71 \%)$ & $8(57.14 \%)$ \\
\hline Low & & $20(13.33 \%)$ & $19(13.97 \%)$ & $1(07.14 \%)$ \\
\hline $\mathrm{MCH}(\mathrm{pg})$ & $27.00-32.00$ & & & \\
\hline High & & $3(2.00 \%)$ & $29(21.32 \%)$ & $0(00.00 \%)$ \\
\hline Normal & & $43(28.67 \%)$ & $88(64.71 \%)$ & $9(64.29 \%)$ \\
\hline Low & & $104(69.33 \%)$ & $19(13.97 \%)$ & $5(35.71 \%)$ \\
\hline $\mathrm{MCHC}(\mathrm{g} / \mathrm{dl})$ & $30.00-35.00$ & & & \\
\hline High & & $8(5.33 \%)$ & $8(5.88 \%)$ & $0(00.00 \%)$ \\
\hline Normal & & $62(41.33 \%)$ & $56(41.18 \%)$ & $6(42.86 \%)$ \\
\hline Low & & $80(53.33 \%)$ & $72(52.94 \%)$ & $8(57.14 \%)$ \\
\hline $\mathrm{PLT} \times 10^{9} / \mathrm{L}$ & $150.00-400.00$ & & & \\
\hline High & & $45(30.00 \%)$ & $41(30.15 \%)$ & $4(28.57 \%)$ \\
\hline Normal & & $75(50.00 \%)$ & $67(49.26 \%)$ & $8(57.14 \%)$ \\
\hline Low & & $30(20.00 \%)$ & $28(20.59 \%)$ & $2(14.29 \%)$ \\
\hline MPV (fl) & $8.00-15.00$ & & & \\
\hline High & & $0(00.00 \%)$ & $0(00.00 \%)$ & $0(00.00 \%)$ \\
\hline Normal & & $127(84.67 \%)$ & $116(85.29 \%)$ & $11(78.57 \%)$ \\
\hline Low & & $23(15.33 \%)$ & $20(14.71 \%)$ & $3(21.43 \%)$ \\
\hline $\operatorname{ESR}(\mathrm{mm} / \mathrm{hr})$ & $<20$ & & & \\
\hline High & & $96(64.00 \%)$ & $86(63.24 \%)$ & $10(71.43 \%)$ \\
\hline Normal & & $54(36.00 \%)$ & $50(36.76 \%)$ & $4(28.57 \%)$ \\
\hline
\end{tabular}

\section{Discussion}

This study revealed that, females are more co-infected with HIV (64.29\%) than the males with $35.71 \%$ possibly due to their inadequate awareness of the mode of transmission of the two disease causing microorganisms and also probably due to the practice of polygamy which sometimes give room for a single infected household man to infect two or more wives in their matrimonial rooms/homes, and other factors like unfaithfulness of some of the men that travel far away for business or hand works for months and later bring back home the HIV to their innocent wives. An attempt was made to study some of haematological parameters among the said patients with and without HIV infection. In this study $30 \%$ of the PTB and $21 \%$ of the PTB/HIV positive patients had developed anaemia; prevalence of anaemia is lower compared to studies conducted in Northwestern Ethiopia (46\% and 60\%) [9], 31.9\% in Korea [11], $73 \%$ in Iran [12] and 74\% in India [13], 85\% in Khartum State of Sudan [14], 64\% in a study conducted in Tanzania [15] and $66.67 \%$ in Dhaka, Bangladesh [16], this may be as a result of the availability of many nutritious classes of food such as fish, vegetables, fruits, and seeds that are easy to be cultivated, caught or sometimes bought from the nearby markets or river sites which argument their nutritional diets as they are very important during red blood cells production in the bone marrow thereby contributing toward success in treating the pulmonary tuberculosis disease in the study areas. Though the result of this study shows low anaemia percentage when compared with the previous studies but $30 \%$ and $21 \%$ are still considered as high anaemia prevalence. The high prevalence of anaemia is supported by several studies which showed that high prevalence of anaemia among pulmonary tuberculosis patients with and without HIV infection. Various pathogeneses have been suggested in TB associated anaemia, but must studies showed infection of the haematopoietic progenitor cells, effect of treatment on erythropoiesis and folate activity, nutritional deficiencies and malabsorption, absence or depletion of bone marrow iron, and suppression of erythropoiesis by inflammatory mediators as a potential explanation for TB-HIV related anaemia [15]. For instance, it has been reported that mild to moderate anaemia is common during chronic inflammatory infections, including TB [17]. The high percentage of anaemia may due to the influence of proinflammatory cytokines, such as Interleukin-6 (IL-6) and TNF-a, which may in turn impair erythropoiesis [18].

In this study, the WBC count showed the level of Leucopenia to $27.94 \%$ and $64.29 \%$ among PTB and $\mathrm{PTB} / \mathrm{HIV}$ co-infected patients respectively, these values were higher than $6 \%$ and $14 \%$ leucopenia of $\mathrm{PTB}$ and PTB/HIV co-infected patients reported in Northwestern Ethiopia by [9]. These observed differences might be due to HIV coinfection. Leucopenia in HIV infection might be due to decrease in bone marrow production of granulocyte progenitor cells [19].

The mean value of MID count of PTB/HIV negative patients was higher as compared to PTB/HIV co-infected patients in this study $(1.11 \pm 0.43$ and $0.70 \pm 0.56)$ with $54.41 \%$ and $35.71 \%$ prevalence respectively. Since the subjects included in this study were those with active tuberculosis, polymorphonuclear leukocytes (neutrophils) may be increased as part of the immune defense mechanism to defend the $M$. tuberculosis infection. Low MID count (26.47\% and 64.29\%) in PTB/HIV negative and PTB/HIV positive patients respectively may be due to consequences of the combined effect of hypersplenism and marrow granulopoietic failure 
mediated by different cytokines and malnutrition [20].

The other haematological parameter assessed in this study was platelet count. The result showed a statistically significant higher platelet count in PTB/HIV patients when compared to PTB/HIV co-infected patients $(317 \pm 0.98$ versus $291 \pm 0.03)$. The finding is supported by studies in Babylon province and Kirkuk city, Iraq [21, 22], and Pakistan [19], and the values are higher when with 111.9 recorded in Calabar, Nigeria [23]. Also $30 \%$ of the study population have high platelets count, this was lower when compared with studies conducted in Dhaka, Bangladesh with $80 \%$ [16] and East London by Morris et al., 1989, that recorded 52\% elevated platelet count, and the result is higher when compared with $8 \%$ in Hungary [24]. These differences may be attributed to the reactive thrombocytosis which was found in a number of clinical situations including infectious diseases such as pulmonary tuberculosis due to increased thrombopoietic factors such as IL-6 which is released by inflamed cell as an inflammatory response [18]. The secretion of IL-6 in PTB patients will stimulate the production of platelets [25]. Some studies also reported the presence of autoantibody complexes as being responsible for the mild decreased platelet count in PTB/HIV infection [26].

The prevalence of thrombocytopenia among PTB patients was $20.00 \%$ while it was $14.29 \%$ among PTB/HIV coinfected patients. Different mechanisms such as immune mechanisms, bone marrow fibrosis, direct megakaryocyte infection, and hypersplenism had been implicated as possible causal factors for thrombocytopenia in PTB/HIV co-infected patients [27].

High ESR values were found in both PTB and PTB/HIV co-infected patients $(44.45 \pm 0.71$ and $52.57 \pm 3.12)$ with $64 \%$ of the whole study population having high ESR values. $44.45 \mathrm{~mm} / \mathrm{hr}$ and $52.57 \mathrm{~mm} / \mathrm{hr}$ values are lower when compared with research conducted in Calabar, Nigeria with the mean ESR values of $104.2 \mathrm{~mm} / \mathrm{hr}$ [23], Ludhiana city, India by [28] who found $66.86 \mathrm{~mm} / \mathrm{hr}$ ESR values among TB patients and $64.3 \mathrm{~mm} / \mathrm{hr}$ found in Pakistan by [29]. 64\% is also low when compared with the result of [16] who recorded $93.33 \%$ of the TB patients having high values above the normal range. ESR value usually increased with the pulmonary tuberculosis [30]. Elevated ESR to a different level is one of the indicators of the severity of disease and as a prognostic tool. This might be due to alterations in the plasma proteins [31] which in turn affect ESR values. The higher ESR values could also be as a result of inflammation and degenerative changes (these are general features of PTB) due to increase in production of acute phase protein, reduced albumin, often observed in chronic infections and release of proteins by the causative organism into the circulation [32].

\section{Conclusion}

In this study, different haematological abnormalities in pulmonary tuberculosis with or without HIV infection were observed. There was high prevalence of leucopenia, followed by neutropenia (MID) and anaemia, lymphocytopenia and thrombocytopenia in sequential order, the $\mathrm{MCH}$ and $\mathrm{MCHC}$ low values were very prevalent among the PTB patients, there was also high ESR values among more than two-third of the whole pulmonary tuberculosis patients studied. Leucocytes (WBCs), Lymphocytes, MID (Neutrophils, Eosinophils, and Basophils), granulocytes, Erythrocytes, packed cells volume, and platelet counts showed statistical significant difference between pulmonary tuberculosis with and without HIV patients. A high ESR value was recorded in all the study participants. The study also pointed out that females were more co-infected with HIV (64.29\%) than the males with $35.71 \%$. Assessment of haematological parameters can be used as an indicator in the diagnosis and follow-up of pulmonary tuberculosis patients with or without HIV for various haematological disorders such as anaemia, increased ESR, thrombocytosis, thrombocytopenia and leucopenia. In addition, knowledge of these haematological pictures will enhance the overall management of the PTB patients with regard to monitoring the disease progression and response to antimicrobial chemotherapy as they will serve as useful indicators for treatment success or failure.

\section{References}

[1] Cole S. T, Brosch R, and Parkhil J, Garnier T, Chucher C, Harris D, and Barrell B. G, (1998). "Deciphering the biology of Mycobacterium tuberculosis from the complete genome Sequence”. Pub Med Central. PMID 9634225.

[2] Global tuberculosis report 2019. Geneva: World Health Organization; 2019. Licence: CCBY-NC-SA 3.0 IGO. ISBN 978-92-4-156571-4.

[3] Lawanson A, and Emperor U, (2019). "Nigeria to expand diagnosis and treatment of tuberculosis", NTBLCP 2019 preworld tuberculosis day press briefing. Abuja. The Nation News Paper.

[4] WHO (2017). "HIV/AIDS Fact Sheet." Geneva: WHO Media Centre, updated July 2017.

[5] NACA (2017), "National Strategic Framework on HIV and AIDS, 2017 -2021." Abuja, National Agency for the Control of AIDS.

[6] Global Funds to fight AIDS, Tuberculosis \& Malaria, 2017, Geneva, Switzerland, website@theglobalfund.org.

[7] Amilo G. I, Meludiu S. C, Ele P. U, Ezechukwu C, Onyenekwe C, and Ifeanyi C. M, (2013), Haematologic Indices in pulmonary Tuberculosis with and without HIV Coinfection in South Eastern Nigeria, Advances in Life Sciences and Technology, vol. II, 2013.

[8] Hoffbrand A. V, and Petit J. E, (2005). "Clinical Haematology", 3rd Edition. Mosby, London, Wiley \& Sons Ltd Publishers.

[9] Faven A, Aregawi Y, Agumas S, and Bamlaku E, (2018). "Haematological Abnormalities of pulmonary tuberculosis patients with and without HIV at the University of Gondar Hospital, Northwest Ethiopia": A comparative cross-sectional studies". Tuberculosis Research and Treatment Journal, Volume 2018. 
[10] NPC, and NBS, (2017). "National Population Commission of Nigeria and National Bureau of Statistics." Abuja. www.nigerianstat.gov.ng.

[11] Sei W. L, Young A. K, Young S. Y, Sang-Won U, Sang M. L, Chul-Gyu Y, Young W. K, Sung K. H, Young-Soo S, and JaeJoon Y. (2006). "The prevalence and evolution of anemia associated with tuberculosis," Journal of Korean Medical Science, vol. 21, no. 6, pp. 1028-1032, 2006. PMID: 1717968 .

[12] Tabarsi P, Mirsaeidi S. M, Amiri M, Mansouri S. D, Masjedi M. R, and Velayati A. A, (2008). "Clinical and laboratory profile of patientswith tuberculosis/HIVcoinfection at a national referral centre: Acase series," EasternMediterraneanHealth Journal, Vol. 14, no. 2, pp. 283291.

[13] Yaranal P. J, Umashankar T, and Harish S. G, (2013) "Hematological profile in pulmonary tuberculosis," International Journal of Health and Rehabilitation Sciences, vol. 2 , no. 1 , pp. 50-55.

[14] Mohammed Abaker Saeed, (2013). "Measurement of Some Haematological parameters among Patients with pulmonary Tuberculosis in Khartoum State, Sudan”. University of Science and Technology, College of Medical Laboratory Science, 2013.-52p.: ill.; 28cm.-M. sc. http://repository.sustech.edu/handle/123456789/3503.

[15] Isanaka S, Mugusi F, Urassa W, Willett W. C, Bosch R. J, Villamor E, Spiegelman D, Duggan C, and Fawzi W. W, (2012), "Iron deficiency and anemia predict mortality in patients with tuberculosis," Journal of Nutrition, vol. 142, no. 2, pp. 350-357, 2012.

[16] Tasnuva, T. and Sanjida, H. T., (2013). "An Evaluation of Sputum smear conversion and Haematological parameter alteration in early detection period of new pulmonary tuberculosi (PTB) patients". International Journal of Medicine, Health, Biomedical, Bioengineering and Pharmaceutical Engineering. Vol. 7, No. 1, 2013.

[17] Baynes R. D., Flax H., Bothwell T. H, Bezwoda W. R, MacPhall A. P, Atkinson P, and Lewis D, (1986). "Haematological and Iron-related measurements in active pulmonary tuberculosis." European Journal of Haematology, Vol. 36, no. 3, pp. 280-287.

[18] Singh P. P, and Goyal A, (2013). Interleukin-6: a potent biomarker of Mycobacterial infection, Springer plus, vol. 2, Article 686.

[19] Shafee M, Abbas F, Ashraf M, Mengal M. A, Kakar N, Ahmad Z and Ali F, (2014). "Hematological profile and risk factors associated with pulmonary tuberculosis patients in Quetta, Pakistan," Pakistan Journal of Medical Sciences, vol. 30, no. 1, pp. 36-40, 2014.

[20] Sharma S. K, Pande J. N, Singh Y. N, Verma K, Kathait S. S, Khare S. D, and Malaviya, (1992). "Pulmonary function and immunologic abnormalities in Miliary tuberculosis." American Review of Respiratory Disease, vol. 145, no. 5, pp. 1167-1171, 1992.
[21] Al-muhammadi, M. O, and Al-Shammery H. G, (2011) "Studying Some Hematological Changes in Patients with Pulmonary Tuberculosis in Babylon Governorate," Medical Journal of Babylon, Vol. 8, no. 4.

[22] Shareef H. A, and Amin N. R. M, (2012). "Abnormalities of hematological parameters in newly diagnosed Pulmonary tuberculosis patients in Kirkuk city," Journal of University of Babylon, vol. 20, no. 5, pp. 1486-1492, 2012.

[23] Okafor, I. M., Eyo, A. O., Okon E. A. and Akpan, P. A. (2013). "Some Haematological parameters of Tuberculosis infected Nigerians: A case study in Calabar - Nigeria". Global Journal of Pure and Applied sciences, Vol. 19, 2013 pp. 98 99.

[24] Bozoky, G., Ruby, E., Goher, I., Toth, J. and Mohos, A. (1997). "Hematologic abnormalities in pulmonary tuberculosis", Orvosi Hetilap, April, 1997, Vol. 138, issue 17, pp. 1053-1056.

[25] Yan S. L. S, Russell J, and Granger D. N, (2014). "Platelet activation and platelet-leukocyte aggregation elicited in experimental colitis are mediated by interleukin-6." Inflammatory Bowel Diseases, Vol. 20, no. 2, pp. 353-362.

[26] Mugusi F. M, Mehta S, Villamor E, Willy U, Elmar S, Ronald J. B, and Wafaie W. F, (2009). "Factors associated with mortality in HIV-infected and uninfected patients with pulmonary tuberculosis," BMCPublicHealth, vol. 9, no. 1, p. 409, 2009.

[27] Panda S., Meher L. K., Dalai S. P., Nayak S., and Tripathy S. K, (2016). "A case of immune thrombocytopenic purpura secondary to pulmonary tuberculosis," Journal of Clinical and Diagnostic Research, vol. 10, no. 10, pp. OD12-OD13, 2016.

[28] Kaur, K. P., Arora, B., Chhina, D. K., and Gupta, V. (2012). "Comprehensive evaluation of patient characteristics and clinical parameters as a diagnostic aid in tuberculosis". The International Journal of Laboratory Medicine, Vol. 5, no 1.

[29] Talat, T., Bhatti, B. M., and Yaqoob, M. (2002). "Comparative efficacy of different laboratory techniques used in diagnosis of tuberculosis in human population", Journal of Medical Sciences, 2002, Vol. 2, issue 3 pp. 137-44.

[30] Mandal S. K, and Chavan L, (2016). "Erythrocyte Sedimentation Rate Values in Cases of Active Tuberculosis without HIV Co-Infection." Journal of Medical Science and Clinical Research, vol. 04, no. 10, pp. 13156-13159, 2016.

[31] Paton N. I, Ng Y, Chee C. B, Persaud C, and Jackson A. A, (2003). "Effects of tuberculosis and HIV infection on wholebody protein metabolism during feeding, measured by the [15N] glycine method," American Journal of Clinical Nutrition, vol. 78, no. 2, pp. 319-325, 2003.

[32] Willey J. M, Sherdhood L. M, and Woolveton C. J. (Eds) (2018). Mycobaterium tuberculosis infections. Prescott, Harley, and Klein's Microbiology 7th edition, pp 951-955. 